\title{
Causes of morphological discontinuities in soils of Depressão Central, Rio Grande do Sul State, Brazil
}

\author{
Cristiane Regina Michelon ${ }^{1}$; Antonio Carlos de Azevedo ${ }^{2 *}$; Fabrício de Araújo Pedron ${ }^{3}$; \\ Ricardo Simão Diniz Dalmolin ${ }^{3}$; Sidinei Klochnner Stürmmer ${ }^{1}$; Juliana Gonçalves ${ }^{1}$; Sérgio \\ Luis de Jesus ${ }^{4}$

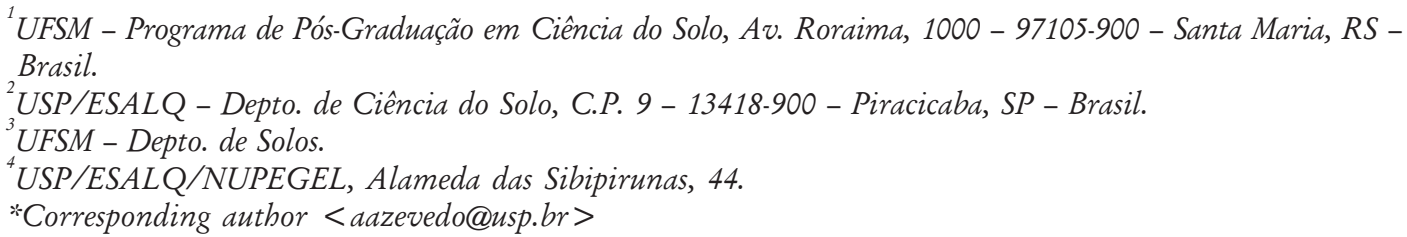

ABSTRACT: Morphological, particularly textural, discontinuities between horizons increase soil erodibility in Depressão Central, Rio Grande do Sul State (Brazil). Characterization of such discontinuities would help to understand landscape evolution and to model near-surface hydrology. The objective of this research was to explore the relationship between morphological discontinuity and deposition of transported materials during pedogenesis. Transported material was meant to be mineral particles found in the soil profile, transported probably by water or gravity, that were not present neither in the parent material nor derived from it. Five soils of this region (two Alfisols, two Ultisols and one Mollisol) were sampled and morphological, sand grain size statistics, chemical and mineralogical analyses were used to search for evidences of deposition of transported materials. Two soils had abrupt textural change but no evidence of deposition of transported materials, two soils had less contrasting morphology and some characteristics that are possibly related to deposition, and one soil had no morphological discontinuity, but had deposition of material enriched in magnetite-maghemite in the sand fraction of the A horizon. Therefore, there were no relationship between morphological discontinuity and deposition of transported materials for these profiles in the Depressão Central.

Key words: soil morphology, subtropical soils, soil discontinuity

\section{Causas das descontinuidades morfológicas em solos da Depressão Central, Rio Grande do Sul, Brasil}

\begin{abstract}
RESUMO: Contrastes morfológicos entre horizontes, e particularmente os contrastes texturais, aumentam a erodibilidade do solo na Depressão Central do Rio Grande do Sul (Brasil). A caracterização destes contrastes contribui para a compreensão da evolução da paisagem e para a modelagem da hidrologia de superfície. Cinco solos desta região foram amostrados e a morfologia, distribuição do tamanho de grãos da fração areia, análises químicas e mineralógicas foram usadas para tentativamente relacionar o contraste textural e morfológico com materiais transportados durante a pedogênese. Por materiais transportados entendem-se as partículas minerais presentes no perfil do solo, transportadas provavelmente por água ou gravidade, e que não estavam presentes nem no material de origem e nem foram derivadas deste. Dois solos apresentaram mudança textural abrupta sem evidências de deposição, dois solos apresentaram menor contraste morfológico e evidências que sustentam a possibilidade de deposição e um solo não apresentou contraste morfológico, porém as características indicam deposição de material rico em magnetita-maghemita na fração areia do horizonte A. Portanto, não foi encontrada relação entre descontinuidades morfológicas e deposição de materiais transportados, na Depressão Central. Palavras-chave: morfologia do solo, solos subtropicais, descontinuidades pedogenéticas
\end{abstract}

\section{Introduction}

Morphological discontinuities in soils usually relate to contrasts in characteristics such as texture, color, porosity and mineralogy, which affect soil dynamics (Stiles et al., 2003). In highly weathered, polygenetic soils, it is frequently difficult to identify deposited material based solely on morphological discontinuities, because they can have multiple, concurrent origins (pedogenetic, geological and/ or geomorphological, for example) (Muggler et al., 2007; Phillips and Lorz, 2008). Northcote (1971) coined the term "duplex soils" for the Australian soils that have abrupt textural contrast and Chittleborough (1992) identified six mechanisms that originate them: sedimentary layering, clay formation, clay weathering, clay illuviation, clay alluviation and bioturbation, and later Phillips (2004) classified them into three categories: pedological versus geological origin, processes of textural contrast genesis, and geographical distribution of soils with textural contrast. Phillips and Lorz (2008) attempted to systematize such different views proposing a Vertical Contrast Model, which "incorporated a vari- 
ety of geologic and pedologic processes that create, destroy, enhance or obscure vertical contrasts".

In Brazil, processes of textural discontinuity were related to the deposition of transported material on top of the soils (Luz et al., 1992; Alves and Ribeiro, 1995; Furian et al., 1999), vertical and lateral translocation of clay (Jimenez Rueda and Dematte, 1988) and clay dissolution (Almeida et al., 1997; Schaefer et al., 2002; Simas et al., 2005). In the Coastal Plain of Rio Grande do Sul State, Almeida et al. (1997) concluded that the abrupt textural change in an Albaqualf was related to clay dissolution by ferrolysis. Soils in the Depressão Central are mainly Alfisols and Ultisols with coarse-, moderately coarseor medium-textured A and/or E horizons over clayey B horizons (Brasil, 1973; USDA, 1993; USDA-NRCS, 1999). Present day expansion of urban areas and land use change from pasture to agriculture increase overuse of soil resources, demanding efforts to better characterize soils in Depressão Central (Pierini et al., 2002; de Melo and Cuchierato, 2004; Fabbrin Pires et al., 2005; Jasper et al., 2006).

Identification of deposited material is a difficult task because materials transported within short distances tend to be similar to those in the deposition site. In addition, the weathering and pedogenetic processes can level out differences that would allow recognition of different materials. Several techniques have been used to detect transported materials in soils. Among the most efficient ones is the use of isotopes which greatly improved the study of soil production function (Heimsath et al., 1997; Heimsath et al., 2000) and evolution of weathering profiles (Dosseto et al., 2008), but such technique is less accessible in developing countries.

The Depressão Central region is a plain, lowland area, used for almost a century mainly for crops of paddy rice, because its abundance of water and nearly plain topography make easier to control the water level on the crop fields. Natural or human-controled floods may cause deposition of transported materials.

The main objective of this study was to explore the use of accessible techniques to investigate the relationship between morphological discontinuity and deposition of materials in five soils from Depressão Central, Rio Grande do Sul, Brasil.

\section{Material and Methods}

The soils sampled are representative of the Depressão Central region (Figure 1 and Table 1). Only the P4 soil was not developed from sedimentary parent material (Figure 2). Climate in the region is Cfa (subtropical without dry season) in the Köppen System (Brasil, 1973). The mean temperature of the warmest month (January) is greater than $22^{\circ} \mathrm{C}$ and of the coldest month (June) is between 3 and $18^{\circ} \mathrm{C}$. Annual precipita-

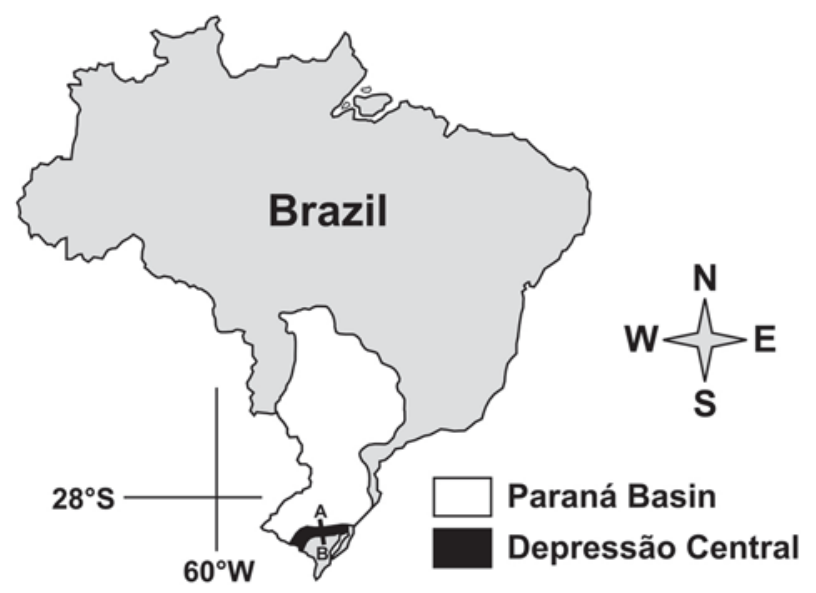

Figure 1 - Location of Parana Basin and Depressão Central. Line from A to B: transect shown in Figure 2. (Based in IBGE, 1986).

Table 1 - Classification, area and parent material of the studied profiles (Based on IBGE, 1986).

\begin{tabular}{|c|c|c|c|c|c|}
\hline \multirow{2}{*}{ Soil } & \multicolumn{2}{|c|}{ Soil Classification } & \multirow{2}{*}{$\operatorname{Area}^{1}(\%)$} & \multirow{2}{*}{ Parent Material } & \multirow{2}{*}{ Location } \\
\hline & Soil Taxonomy & $\mathrm{SiBCS}^{2}$ & & & \\
\hline P1 & Typic Albaqualf & $\begin{array}{l}\text { Planossolo Haplico } \\
\text { Eutrofico arenico }\end{array}$ & 31 & $\begin{array}{l}\text { Alluvial sediment } \\
\text { (Quaternary) }\end{array}$ & $\begin{array}{c}30^{\circ} 15^{\prime} 74^{\prime \prime ~ S} \\
54^{\circ} 32^{\prime} 41^{\prime \prime} \mathrm{W} \\
\text { Alt }^{3} .: 118 \mathrm{~m}\end{array}$ \\
\hline $\mathrm{P} 2$ & Aquic Argiudoll & $\begin{array}{l}\text { Planossolo Haplico } \\
\text { Eutrofico tipico }\end{array}$ & 4 & $\begin{array}{c}\text { Shale } \\
\text { (Guata Formation) }\end{array}$ & $\begin{array}{c}30^{\circ} 02^{\prime} 78^{\prime \prime} \mathrm{S} \\
53^{\circ} 40^{\prime} 52^{\prime \prime} \mathrm{W} \\
\text { Alt.:62 m }\end{array}$ \\
\hline P3 & Typic Paleudult & $\begin{array}{l}\text { Argissolo Vermelho } \\
\text { Distrofico arênico }\end{array}$ & 12 & $\begin{array}{c}\text { Sandstone } \\
\text { (Santa Maria Formation) }\end{array}$ & $\begin{array}{c}29^{\circ} 42^{\prime} 77^{\prime \prime} \mathrm{S} \\
53^{\circ} 42^{\prime} 76^{\prime \prime} \mathrm{W} \\
\text { Alt.:76 m }\end{array}$ \\
\hline P4 & Rhodic Paleudult & $\begin{array}{c}\text { Argissolo Vermelho-Amarelo } \\
\text { Distrófico típico }\end{array}$ & 2 & $\begin{array}{c}\text { Sao Sepe Granite } \\
\text { (Riograndense Shield) }\end{array}$ & $\begin{array}{c}30^{\circ} 08^{\prime} 88^{\prime \prime} \mathrm{S} \\
53^{\circ} 35^{\prime} 62^{\prime \prime} \mathrm{W} \\
\text { Alt.:89 m }\end{array}$ \\
\hline P5 & Typic Rhodudalf & $\begin{array}{c}\text { Argissolo Vermelho-Amarelo } \\
\text { Distrofico umbrico }\end{array}$ & 5 & $\begin{array}{l}\text { Claystone and Siltstone } \\
\text { (Itararé Formation) }\end{array}$ & $\begin{array}{c}30^{\circ} 21^{\prime} 81^{\prime \prime} \mathrm{S} \\
54^{\circ} 14^{\prime} 92^{\prime \prime} \mathrm{W} \\
\text { Alt.: } 152 \mathrm{~m}\end{array}$ \\
\hline
\end{tabular}

${ }^{1}$ Percentage of Depressão Central area. ${ }^{2}$ Brazilian Soil Classification System (EMBRAPA, 2006). ${ }^{3}$ Alt. $=$ Altitude above sea level. 


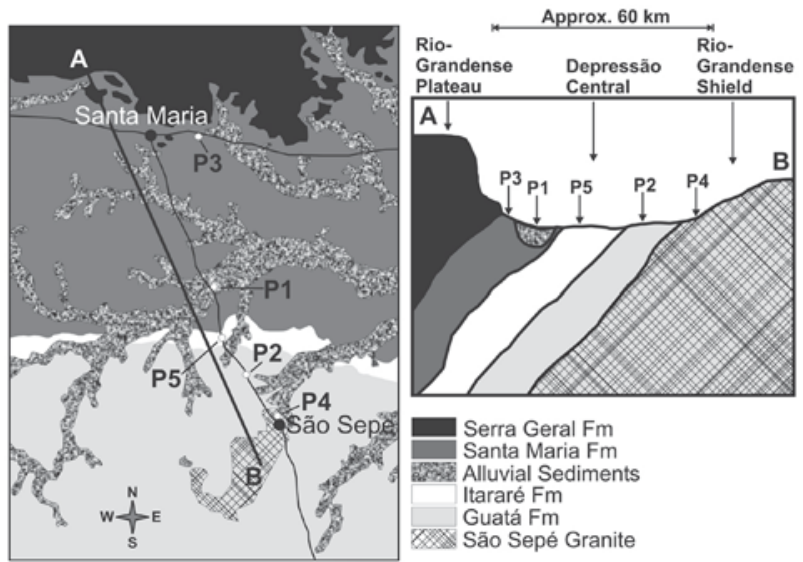

Figure 2 - Geological setting of the transect shown in Figure 1 and sampling sites in Depressão Central. (Based in IBGE, 1986).

tion varies from 1400 to $1600 \mathrm{~mm}$. Excess water averages $750 \mathrm{~mm} \mathrm{yr}^{-1}$. Landscapes in Depressão Central region are dominantly at level or gently undulated (Figure 3).

Soil and parent material were sampled and described with particular attention to color, structure, texture, and topography and distinctness of the boundary between horizons (USDA, 1993). Core samples were also collected with steel rings to measure bulk density (Blake and Hartge, 1986). Particle size analysis was done by pipette method after dispersion with $0.1 \mathrm{M} \mathrm{NaOH}$ and shake for $6 \mathrm{~h}$ (EMBRAPA, 1997) without prior elimination of organic matter and iron oxides. Sand size particles (from 2.0 to $0.05 \mathrm{~mm}$ ) were obtained by wet sieving after dispersion. Sand mass distribution among five size subclasses: 2000 to 1700 micrometers $(\mu \mathrm{m}) ; 1700$ to $850 \mu \mathrm{m} ; 850$ to $425 \mu \mathrm{m} ; 425$ to $212 \mu \mathrm{m} ; 212$ to $106 \mu \mathrm{m}$; and 106 to $53 \mu \mathrm{m}$, was obtained by dry sieving. Sand grain size statistics (Table 3) were calculated using the GSSTAT algorithm (Poppe et al., 2004). To run GSSTAT, grain diameter classes were converted from millimeters $(\mathrm{dmm})$ to phi scale (phi $=-\log 2 \mathrm{dmm})$ and calculated by:

Median $=p h i_{50}$

Graphic Mean $=\left(p h i_{16}+p h i_{50}+p h i_{84}\right) / 3$

Std. Deviation $=\left[\left(p h i_{84}-p h i_{16}\right) / 4\right]+\left[\left(p h i_{95}-p h i_{5}\right) / 6.6\right]$

Skeweness $=\left\{\left[\left(p h i_{16}+p h i_{84}\right)-\left(2 \times p h i_{50}\right)\right] /\left[2 \times\left(p h i_{84}-\right.\right.\right.$ $\left.\left.\left.p h i_{16}\right)\right]\right\}+\left\{\left[\left(p h i_{5}+p h i_{95}\right)-\left(2 \times p h i_{50}\right)\right] /\left[2 \times\left(p h i_{95}-p h i_{5}\right)\right]\right\}$

(eq.4);

Kurtosis $=\left(p h i_{95}-p h i_{84}\right) /\left[2.44 \mathrm{x}\left(p h i_{75}-p h i_{25}\right)\right]$ (eq.5).

In the equations 1 to 5 (Poppe et al., 2004), phi $_{\mathrm{n}}$ is the grain size (phi scale) in a cumulative curve that accumulates the " $n$ " \% of sand mass.

A first approach to identify deposited material using total element analysis was done based on the ISOCON method (Grant, 2005), considering the mass of
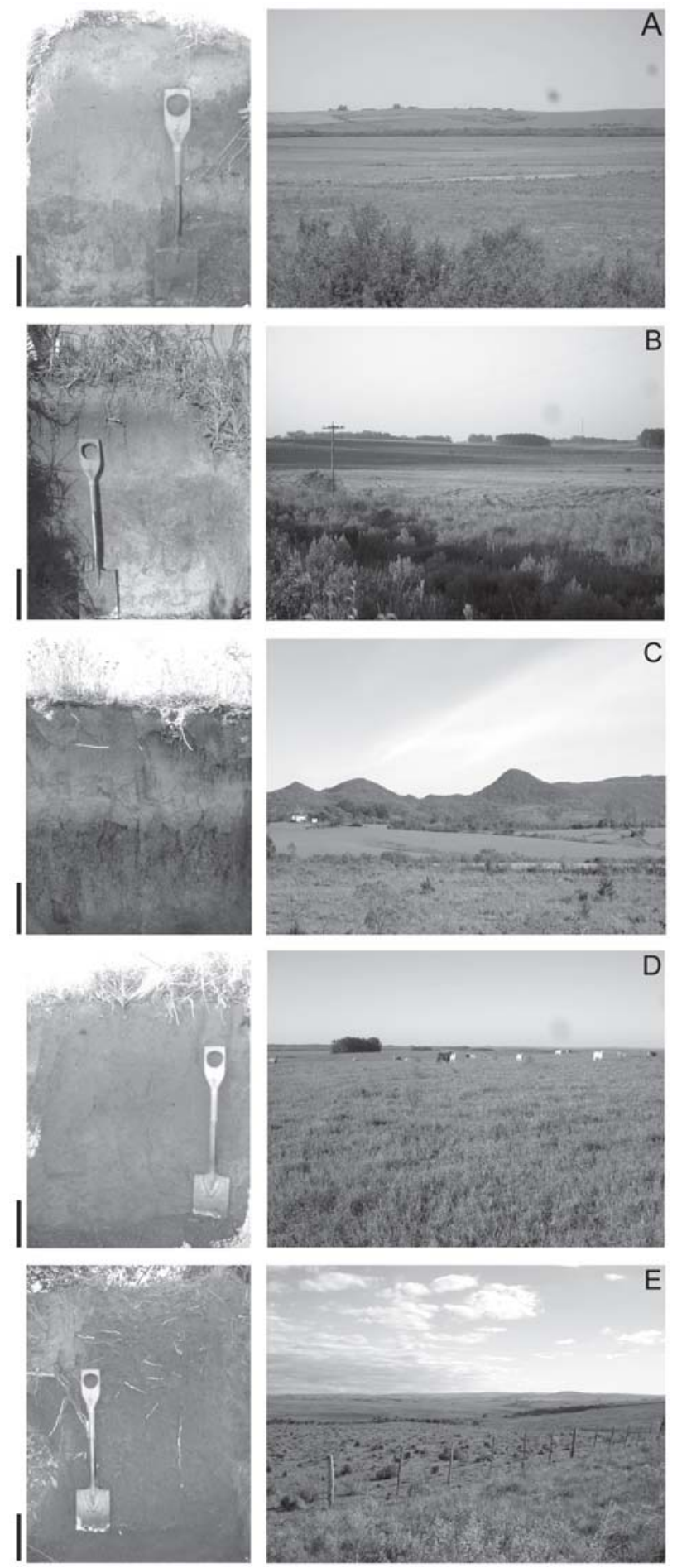

Figure 3 - Profiles studied (left) and landscape associated (right). A. Profile P1; B. Profile P2; C. Profile P3; D. Profile $\mathrm{P} 4$ and E. Profile P5. Scale bar $=0.20 \mathrm{~m}$.

parent material and soil as constant during the alteration. This assumption is reasonable for the profiles developed from sedimentary parent material (P1, P2, P3 and P5) since most of the easy weatherable minerals are absent or rare in their composition. Because of that, changes in volume are usually more expressive than change in mass. Based on this assumption, the ratio $R_{i}$ 
Table 2 - Selected morphological characteristics of the studied profiles (Based on IBGE, 1986).

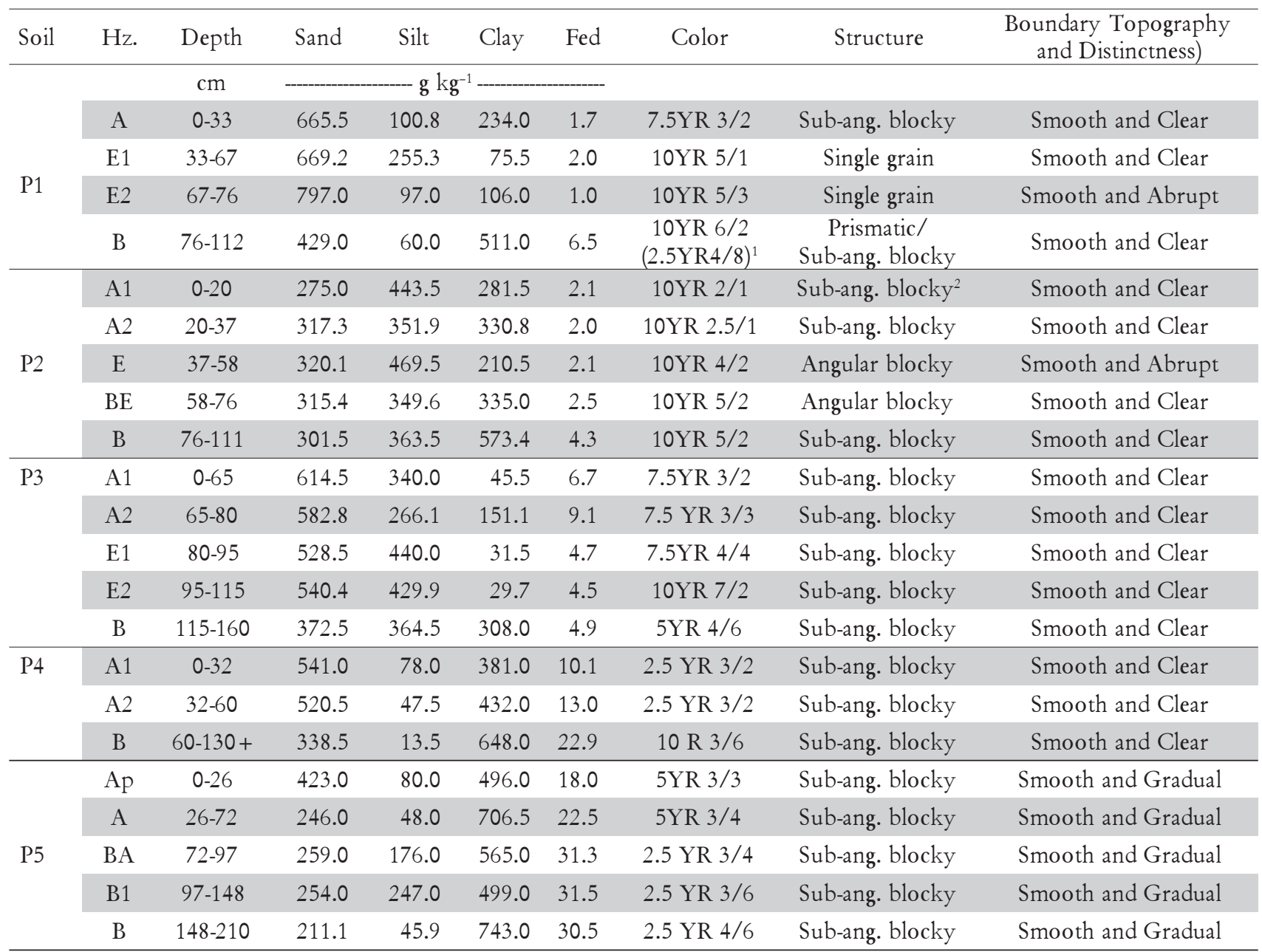

${ }^{1}$ mottles. ${ }^{2}$ Sub-ang. Blocky $=$ Sub-angular blocky.

Table 3 - Sand grain size statistics and interpretation.

\begin{tabular}{|c|c|c|c|c|c|c|c|}
\hline Profile & Horizon & Median & Graphic Mean & Standard Deviation & Skewness & Kurtosis & Coefficient of Variation (\%) \\
\hline \multirow{3}{*}{ P1 } & A & 0.54 & 0.55 & 0.68 (MWS)* & 0.01 (NS) & $1.20(\mathrm{~L})$ & 0.34 \\
\hline & E2 & 0.55 & 0.57 & 0.67 (MWS) & $0.00(\mathrm{NS})$ & $1.18(\mathrm{~L})$ & 1.05 \\
\hline & B & 0.54 & 0.55 & 0.68 (MWS) & $0.00(\mathrm{NS})$ & $1.19(\mathrm{~L})$ & 1.10 \\
\hline \multirow{3}{*}{$\mathrm{P} 2$} & A1 & 0.67 & 0.69 & $1.11(\mathrm{PS})$ & $0.13(\mathrm{FS})$ & $1.07(\mathrm{M})$ & 0.20 \\
\hline & $\mathrm{E}$ & 0.76 & 0.77 & 1.13 (PS) & $0.11(\mathrm{FS})$ & $1.10(\mathrm{M})$ & 0.69 \\
\hline & $\mathrm{B}$ & 0.63 & 0.67 & $1.10(\mathrm{PS})$ & $0.15(\mathrm{FS})$ & $1.10(\mathrm{M})$ & 1.29 \\
\hline \multirow{3}{*}{ P3 } & A1 & 0.84 & 0.90 & $1.11(\mathrm{PS})$ & $0.16(\mathrm{FS})$ & $1.17(\mathrm{~L})$ & 0.59 \\
\hline & E1 & 0.61 & 0.62 & $0.80(\mathrm{MS})$ & $0.01(\mathrm{NS})$ & $1.01(\mathrm{M})$ & 1.25 \\
\hline & $\mathrm{B}$ & 0.96 & 0.86 & $0.78(\mathrm{MS})$ & $0.22(\mathrm{CS})$ & $0.96(\mathrm{M})$ & 1.33 \\
\hline \multirow{2}{*}{ P4 } & A2 & 1.56 & 1.60 & $1.28(\mathrm{PS})$ & $0.02(\mathrm{NS})$ & $1.08(\mathrm{M})$ & 2.43 \\
\hline & $\mathrm{B}$ & 2.11 & 2.03 & 1.47 (PS) & 0.14 (CS) & $0.80(\mathrm{P})$ & 3.32 \\
\hline \multirow{2}{*}{ P5 } & A & 0.96 & 0.82 & 0.99 (MS) & $0.15(\mathrm{CS})$ & $0.88(\mathrm{P})$ & 2.60 \\
\hline & B & 0.71 & 0.64 & $1.01(\mathrm{PS})$ & $0.04(\mathrm{NS})$ & $0.83(\mathrm{P})$ & 7.22 \\
\hline
\end{tabular}

*Classification according to Poppe et al., 2004 ( $\mathrm{n}=3$ ). Standard Deviation: MWS = Moderately Well Sorted; PS = Poorly Sorted; MS = Moderately Sorted; Skewness: NS = Near Symmetrical; FS = Fine Skewed; CS = Coarse skewed. Kurtosis: $\mathrm{L}$ = Leptokurtic; $\mathrm{M}=$ Mesokurtic; $\mathrm{P}$ = Platykurtic. 
Table 4 - Total elemental concentration, $\mathrm{R}_{\mathrm{i}}$ and $\mathrm{Fe}_{\mathrm{d}} / \mathrm{Fe}_{\mathrm{t}}$ ratio for selected horizons.

\begin{tabular}{|c|c|c|c|c|c|c|c|c|c|c|c|}
\hline \multirow{2}{*}{ Soil } & \multirow{2}{*}{$\mathrm{Hz}$. } & \multicolumn{6}{|c|}{ Elemental Analysis (XRF) } & \multicolumn{3}{|c|}{$\mathrm{R}_{2}^{\mathrm{i}}$} & \multirow{2}{*}{$\mathrm{Fe}_{\mathrm{d}} / \mathrm{Fe}$} \\
\hline & & $\mathrm{SiO}_{2}$ & $\mathrm{Al}_{2} \mathrm{O}_{3}$ & $\mathrm{Fe}_{2} \mathrm{O}_{3}$ & $\mathrm{TiO}_{2}$ & $\mathrm{CaO}$ & $\mathrm{MgO}$ & $\mathrm{R}_{\mathrm{Al}}$ & $\mathrm{R}_{\mathrm{Fe}}$ & $\mathrm{R}_{\mathrm{Ti}}$ & \\
\hline \multirow{5}{*}{ P1 } & & & & - & $\ldots$ & 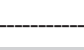 & 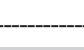 & & & & \\
\hline & $\mathrm{A}$ & 86.97 & 5.05 & 1.36 & 0.645 & 0.12 & 0.20 & 0.40 & 0.40 & 0.81 & 0.18 \\
\hline & E2 & 91.31 & 3.25 & 0.79 & 0.849 & 0.10 & 0.09 & 0.26 & 0.23 & 1.06 & 0.17 \\
\hline & B & 69.70 & 15.17 & 4.58 & 0.836 & 0.34 & 0.57 & 1.20 & 1.36 & 1.05 & 0.20 \\
\hline & $\mathrm{PM}^{1}$ & 80.04 & 12.68 & 3.38 & 0.798 & 0.47 & 0.83 & & & & 0.04 \\
\hline \multirow[t]{4}{*}{ P2 } & A1 & 86.51 & 5.00 & 1.27 & 0.848 & 0.15 & 0.18 & 0.38 & 0.30 & 1.18 & 0.23 \\
\hline & $\mathrm{E}$ & 89.90 & 3.85 & 0.98 & 0.904 & 0.12 & 0.13 & 0.29 & 0.23 & 1.26 & 0.31 \\
\hline & $\mathrm{B}$ & 86.00 & 6.22 & 1.73 & 0.817 & 0.19 & 0.24 & 0.47 & 0.40 & 1.14 & 0.36 \\
\hline & PM & 85.17 & 13.21 & 4.30 & 0.719 & 1.49 & 1.27 & & & & 0.41 \\
\hline \multirow[t]{4}{*}{ P3 } & A1 & 91.35 & 2.51 & 1.64 & 1.331 & 0.02 & 0.09 & 0.17 & 0.29 & 1.08 & 0.58 \\
\hline & E1 & 78.91 & 7.13 & 7.74 & 1.296 & 0.02 & 0.17 & 0.49 & 1.39 & 1.06 & 0.09 \\
\hline & B & 73.90 & 13.30 & 3.79 & 0.679 & 0.38 & 0.60 & 0.90 & 0.68 & 0.55 & 0.76 \\
\hline & $\mathrm{PM}$ & 68.43 & 19.30 & 6.98 & 1.199 & 0.06 & 0.26 & & & & 0.22 \\
\hline \multirow[t]{3}{*}{ P4 } & A2 & 74.33 & 12.68 & 3.73 & 1.021 & 0.06 & 0.18 & 0.54 & 1.12 & 4.07 & 0.50 \\
\hline & B & 62.31 & 20.76 & 5.83 & 0.893 & 0.06 & 0.26 & 0.89 & 1.76 & 3.56 & 0.56 \\
\hline & PM & 58.60 & 23.39 & 3.32 & 0.251 & 0.15 & 0.07 & & & & 0.25 \\
\hline \multirow[t]{3}{*}{ P5 } & A & 63.47 & 19.46 & 6.38 & 1.454 & 0.02 & 0.15 & 4.71 & 2.86 & 1.15 & 0.50 \\
\hline & B & 92.00 & 2.50 & 1.65 & 1.337 & 0.02 & 0.11 & 0.61 & 0.74 & 1.05 & 2.64 \\
\hline & PM & 87.48 & 4.13 & 2.23 & 1.269 & 0.03 & 0.13 & & & & 1.50 \\
\hline
\end{tabular}

'PM: Parent Material. ${ }^{2} \mathrm{R}_{\mathrm{i}}$ is the ratio of concentration of element " $\mathrm{i}$ " between soil horizons and parent material (see text).

was defined as:

$\mathrm{R}_{\mathrm{i}}=\mathrm{M}_{\mathrm{i}}^{\mathrm{A}} / \mathrm{M}_{\mathrm{i}}^{0}$

$\mathrm{M}_{i}^{\mathrm{A}}$ is the mass of element $i$ in the altered material (soil) and $\mathrm{M}_{i}^{0}$ in the parent material (Table 4). Among the chemical elements determined by the XRF technique, $\mathrm{Ti}$ is mainly found in mineral particles more resistant to weathering and in the coarse size class, such as titanomagnetite, anatase and rutile. Therefore, profiles with variation in $R_{T i}$ in the range $1 \pm 0.25$ among the soil horizons and parent material were selected as those with smaller probability to have transported material contribution to its genesis, and had then their chemical balance calculated (Table 5).

The chemical mass balance was calculated using the FLUX algorithm (Biddle et al., 1998), based on the total element content in samples, and assuming titanium ( $\mathrm{Ti}$ ) as immobile element during the profile development. Mass balance was calculated for $\mathrm{Al}, \mathrm{Fe}, \mathrm{Ca}$ and $\mathrm{Mg}$.

Total content of $\mathrm{Si}, \mathrm{Al}, \mathrm{Fe}, \mathrm{Ti}, \mathrm{Ca}$ and $\mathrm{Mg}$ in samples was determined by X-ray fluorescence (XRF) using a Philips PW2400 equipment, according to the procedures described in Mori et al. (1999). Mineral phases were identified by X-ray diffraction (XRD), in a Phillips PW diffractometer with copper anode $\left(\mathrm{Cu} \mathrm{K}_{\mathrm{a}}\right)$ and $\mathrm{Ni}$ filter operated at $40 \mathrm{kV}$ and $40 \mathrm{~mA}$, at 1.2 two theta degrees per minute. Sample preparation followed procedures described in Whittig and Allardice (1986).
Table 5 - Elemental mass balance of P1, P2 and P5 profiles.

\begin{tabular}{|c|c|c|c|c|c|}
\hline Soil & Horizon & $\mathrm{Al}$ & $\mathrm{Fe}$ & $\mathrm{Ca}$ & $\mathrm{Mg}$ \\
\hline & & & - & $\ldots$ & \\
\hline \multirow{3}{*}{ P1 } & A & $-26.81^{1}$ & -35.11 & -48.89 & -42.32 \\
\hline & E2 & -40.12 & -54.57 & -57.17 & -54.15 \\
\hline & B & 7.50 & 20.52 & -22.11 & -20.76 \\
\hline \multirow{3}{*}{ P2 } & A1 & -35.89 & -52.42 & -65.36 & -53.05 \\
\hline & E1 & -40.60 & -57.26 & -66.88 & -55.39 \\
\hline & $\mathrm{B}$ & -30.95 & -45.17 & -63.44 & -50.27 \\
\hline \multirow{2}{*}{ P5 } & A2 & 164.53 & 104.69 & -29.88 & 0.42 \\
\hline & B & -22.48 & -20.82 & -26.24 & -11.86 \\
\hline
\end{tabular}

${ }^{1} \mathrm{Negative}$ numbers indicate percent loss as compared to parent material, after corrected for strain. Positive numbers indicate gain.

Iron in pedogenetic, secondary oxides $\left(\mathrm{Fe}_{\mathrm{d}}\right)$ was determined after reduction with sodium dithionite in a water bath $\left(80^{\circ} \mathrm{C}\right)$ using citrate as complexing agent and bicarbonate as a buffer, as described in Mehra and Jackson (1960).

\section{Results and Discussion}

The P1 soil (Typic Albaqualf) had a sharp increase in clay, change in type of structure and abrupt boundary, all between the E2 and the B horizon (Table 2). Col- 
ors were not contrasting. Mottles in the B horizon are related to the seasonal water saturation. In the P2 soil (Aquic Argiudoll) the morphological discontinuity features were similar to P1 but the greater amount of 2:1 type phyllosilicates (inherited from the parent material) resulted in darker color due to greater amount of organic matter content, typical of Mollisols. Comparing the E2 and A2 horizons to the $\mathrm{B}$ horizon of the P3 (Typic Paleudult) and P4 (Rhodic Paleudult) soils, it was observed a strong decrease in sand and increase in clay content, parallel to a change in color. The greater amount of iron oxides in the P4 soil, mostly formed by weathering of biotite from the granite parent material, resulted in redder hues that placed this profile in the Rhodic subgroup of Paleudults.

In the P5 soil (Typic Rhodudalf), change in sand grain size statistics may be related to deposition of materials, because pedogenetic processes, in general, do not move sand particles (Birkeland, 1999; USDA-NRCS, 1999; USDA, 1993). However, that characteristic can not be used as an unequivocal evidence of material deposition, since it also may be result of differential weathering of grains with diverse mineralogy and/or bioturbation.

The sand grain size statistics (Table 3) resulted in medians very close to the graphic mean, because all samples had small standard deviation, skewness and kurtosis. It may be related to the grain sorting during the geologic event that deposited the sedimentary parent materials of these soils. The P4 soil is an exception because it was developed from granite, resulting in medians greater than 1 .

In spite of morphological discontinuity among horizons, the $\mathrm{P} 1$ and $\mathrm{P} 2$ soils did not have variation in sand statistics among horizons. In the P3 soil, the E1 and $\mathrm{B}$ had similar statistics, but the A horizon had fine sand enough to change the classification of standard deviation (from poorly sorted to moderately sorted), skewness (from fine skewed to nearly symmetrical) and kurtosis (from leptokurtic to mesokurtic). In the P4 soil, the sand distribution in the $\mathrm{B}$ horizon was platykurtic and coarse skewed, while in the A2 was near symmetrical and mesokurtic. Therefore, the A2 horizon had more fine sand than the B horizon. In the P5 soil, the platykurtic kurtosis indicates a wide range of grain size distribution in both the $\mathrm{A}$ and $\mathrm{B}$ horizons, but skewness indicate increase of coarse sand fraction in the $\mathrm{A}$ horizon.

Variations in sand statistics in P3, P4 and P5 soils may relate to deposition of transported material. However, while the decrease of sand grain size towards the soil surface, observed in the P3 and P4 soils, could be related to the more intense weathering, the occurrence of such mechanism is less supported by the greater amount of coarse sand in surface of the P5 soil, and as the total element and mineralogical results suggest, should be more likely related to deposition of transported material.
The $\mathrm{R}_{\mathrm{Ti}}$ was close to 1 (Table 4 ) in most horizons and profiles (except $\mathrm{P} 4$ and the $\mathrm{B}$ horizon of $\mathrm{P} 3$ ). The ratio of concentration of $\mathrm{Al}_{2} \mathrm{O}_{3}$ in soil and parent material $\left(\mathrm{R}_{\mathrm{A}}\right)$ roughly followed the accumulation of Alphyllosilicate clays in the B horizons of the P1, P2 and P4 soils (Table 2 and Table 4), and the depletion in the E horizon, since gibbsite was not detected by XRD.

In the P3 soil, the high $\mathrm{R}_{\mathrm{Fe}}$ in the E1 horizon (1.39) was the result of Fe-bearing minerals in sand fraction, since secondary $\mathrm{Fe}$ oxides $\left(\mathrm{Fe}_{\mathrm{d}}\right)$ were concentrated in the A horizon (Table 2). The small $\mathrm{R}_{\mathrm{Ti}}$ in the $\mathrm{B}$ horizon is another characteristic that adds to the possibility to material deposition in this soil; in P5, the opposite pattern was observed, i. e., the ratio was more than seven times greater in the A horizon as compared with the $\mathrm{B}$ horizon. In the P4 soil, $\mathrm{R}_{\mathrm{Fe}}$ was greater in the $\mathrm{B}$ horizon and was related to secondary, clay sized $\mathrm{Fe}$ oxides $\left(\mathrm{Fe}_{\mathrm{d}}\right)$ accumulation (Table 2). Different from geologic materials underlying the other profiles, the igneous nature of the material of P4 soil implies that a portion of the original rock mass was lost by dissolution during weathering, therefore residually concentrating Ti-bearing, resistant minerals. Such mechanism is not common in sedimentary rocks, frequently made of pre-weathered materials. This is possibly the reason why the largest $\mathrm{R}_{\mathrm{Ti}}$ was found in P4 soil.

The P5 soil had, as the P1 and P2, a $R_{\text {Ti }}$ close to 1 , but the $R_{\mathrm{Fe}}$ and $\mathrm{R}_{\mathrm{Al}}$ were much greater in the $A$ than in $\mathrm{B}$ horizon, suggesting deposition of materials in the P5 soil surface. A hypothesis can be proposed regarding the deposition of materials at the surface of the P5 profile. The sand grain size statistics (Table 3 ) showed that coarse sand sized material was possibly added to the $\mathrm{A}$ horizon. Because $\mathrm{R}_{\mathrm{Fe}}$ and $\mathrm{R}_{\mathrm{Al}}$ showed an increase (Table 4) not followed by the $\mathrm{Fe}_{\mathrm{d}}$ (Table 2), this material should be enriched in primary $\mathrm{Fe}$ and $\mathrm{Al}$ bearing minerals. Also, the primary mineral(s) would not be Ilmenite $\left(\mathrm{FeTiO}_{3}\right)$, found in the sand fraction of $\mathrm{P} 5$ soil, because it contains $\mathrm{Ti}$ and would affect the $\mathrm{R}_{\mathrm{Ti}}$ (Table 4).

The XRD patterns of the sand fraction of the P5 profile showed a small relative increase in the intensity of the Magnetite-Maghemite $(0.253 \mathrm{~nm})$ peak, as compared to the neighbor peak of Ilmenite $(0.254 \mathrm{~nm})$, observed when comparing the $\mathrm{C}$ and the $\mathrm{A}$ horizon (Figure 4). The same occurred in the silt fraction. These findings agree with the hypothesis of deposition of transported material, enriched in magnetite-maghemite. Also, the increase in elemental $\mathrm{Al}$ would also agree with the more intense peak of 2:1 type phyllosilicate (possible a Hydroxy Interlayered Vermiculite - HIV) in the XRD (Figure 4), which would explain the increase in Al, but not the decrease in Si. Because the elemental composition was measured in the whole sample (sand, silt and clay), it is possible that the decrease in the amount of a $\mathrm{Si}$ phase, quartz in sand fraction for example (Table 2), could not be balanced by the increase in $\mathrm{Si}$ in the 2:1 phyllosilicate in the clay fraction. It is also possible that the $\mathrm{Al}$ increase had been related to the presence of a noncrystalline, $\mathrm{Al}$-rich, phase. 


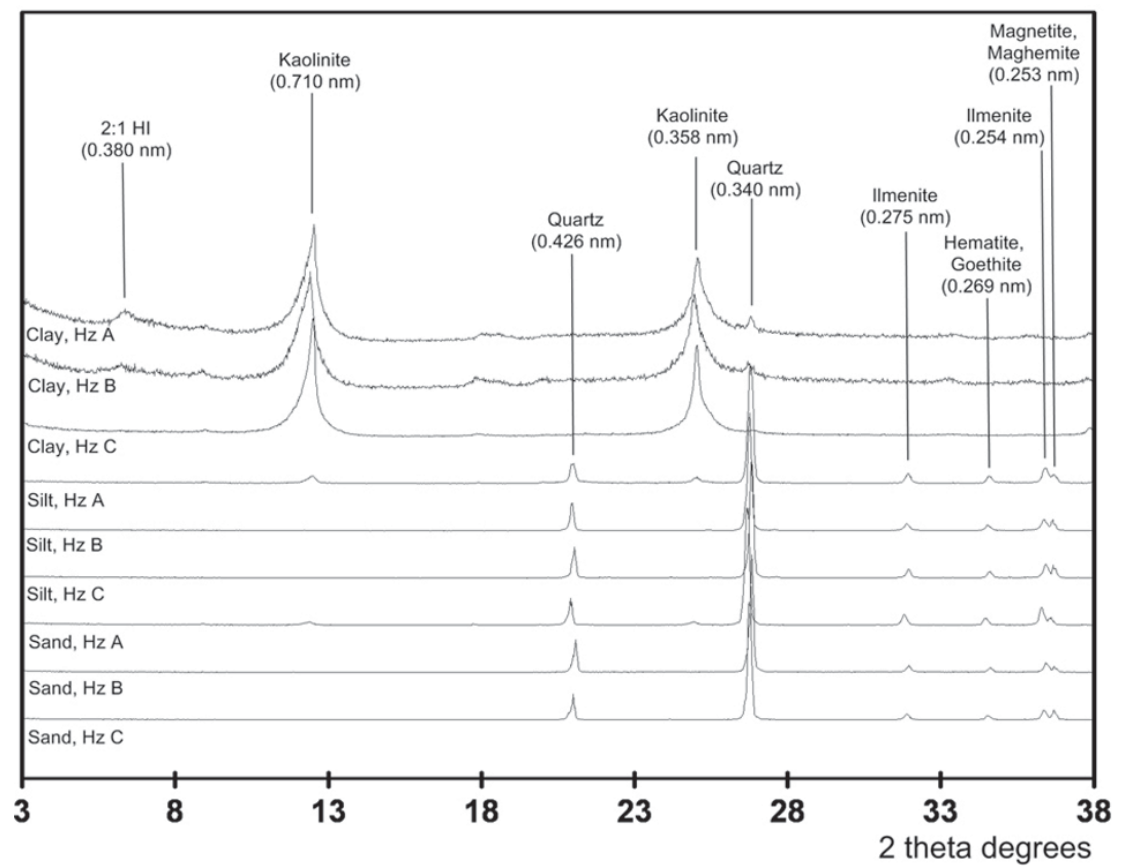

Figure 4 - X-ray diffractogram of sand, silt and clay (deferrified, Mg-saturated) fractions of A, B and C horizons, P5 soil. 2:1 HI: Hydroxy Interlayered 2:1 phyllosilicate.

$\mathrm{P} 1, \mathrm{P} 2$ and $\mathrm{P} 5$ profiles had the $\mathrm{R}_{\mathrm{Ti}}$ within the $1 \pm 0.25$, therefore the mass balance of $\mathrm{Al}, \mathrm{Fe}, \mathrm{Ca}$ and $\mathrm{Mg}$ was calculated for these profiles (Table 5) using $\mathrm{Ti}$ as the index element to correct for strain due to weathering and pedogenesis. In the P5 soil, there was an increase of $\mathrm{Al}$ and $\mathrm{Fe}$ in the $\mathrm{A}$ horizon greater than the amount expected if the concentrations in parent material would be maintained, that is, if there were no loss during pedogenesis. Concurrently, loss of these elements from the A horizon of the other soils were from 20 to $50 \%$. Such results agree with the hypothesis that some material could be deposited on the A horizon. The deposited material could result from erosion from $C$ horizon of a similar soil upslope nearby (considering the paleolandscape, because at present day the slope is gentle, Figure 3), and is probably related to the geomorphologic evolution of the site. An alternative hypothesis is that selective biological activity would transport magnetite-maghemite from the $\mathrm{C}$ horizon towards the A horizon throughout the profile. However, the lack of morphological evidence of bioturbation in the profile weakens this alternative hypothesis.

The chemical mass balance for P1 and P2 soils indicated that these soils had the greatest loss of $\mathrm{Al}, \mathrm{Fe}$, $\mathrm{Ca}$ and $\mathrm{Mg}$ from the $\mathrm{E}$ horizon, and smallest loss, or even gain, in the B horizon, as would be expected if one assumes the greater amount of clay in the B horizon as the result of translocation. The $\mathrm{B}$ horizon of P1 soil had a large increase in $\mathrm{Fe}$, in agreement to the presence of mottles (Table 1), adding to the idea that the abrupt boundary in the P1 soil had pedogenetic origin.
The Depressão Central region is a plain, lowland area, used for almost a century mainly for crops of paddy rice, because its abundance of water and nearly plain topography make easier to control the water level on the crop fields. Natural or human-controlled floods may cause deposition of transported materials.

\section{Conclusions}

Morphological and textural discontinuities were not caused by the deposition of transported materials on top of the profiles in the course of pedogenesis. The less contrasting soils were those with higher possibility of the presence of deposited materials in their composition. The methods of soil and parent material analyses were all useful but for further investigations, they should be chosen based on the type of parent material. Soils derived from sandstones and sediments, besides the grain size characterization, should take advantage of grain morphology and mineralogy. Analysis of soils derived from parent material with Fe bearing minerals should take advantage of selective dissolution and, if possible, magnetic methods. The use of $\mathrm{XRF}$ was also useful but very expensive as compared with the other techniques.

\section{Acknowledgements}

The first author benefited from a CAPES-MEC M.Sc.grant, the second and fourth authors from a CNPq grant for productivity in research. The authors are grateful to an anonymous reviewer whose suggestions greatly improved this paper. 


\section{References}

Almeida, J.A.; Klamt, E.; Kämpf, N. 1997. Origin of textural contrast and degradation of $\mathrm{B}$ horizon in a red yellow Podzolic soil in the coastal Plain of Rio Grande do Sul State, Brazil. Revista Brasileira de Ciência do Solo 21: 221-233. (in Portuguese, with abstract in English).

Alves, A.J.O.; Ribeiro, M.R. 1995. Characterization and genesis of the soils of a toposequence in the dry forest area of Pernambuco State, Brazil. Revista Brasileira de Ciência do Solo 19: 297-305. (in Portuguese, with abstract in English).

Biddle, D.L.; Chittleborough, D.J.; Fitzpatrick, R.W. 1998. An algorithm to model mass balances quantitatively. Computers \& Geosciences 24: 77-82.

Birkeland, P.W. 1999. Soils and Geomorphology. Oxford University Press, New York, NY, USA.

Blake, G.R.; Hartge, K.H. 1986. Bulk density. p. 363-375. In: Klute, A., ed. Methods of soil analysis Part 1: Physical and mineralogical methods. American Society of Agronomy and Soil Science Society of America, Madison, WI, USA.

Brasil. Ministério da Agricultura 1973. Soil Survey of Rio Grande do Sul. Serviço Nacional de Levantamento e Conservação de Solos, Recife, PE, Brazil. (in Portuguese).

Chittleborough, D.J. 1992. Formation and pedology of duplex soils. Australian Journal of Experimental Agriculture 32: 815-825.

De Melo, M.S.; Cuchierato, G. 2004. Quaternary colluvial-eluvial covers of the Eastern Parana Basin, Southeastern Brazil: advances in the quaternary of the Del Plata river basin. Quaternary International 114: 45-53.

Dosseto, A.; Turner, S.P.; Chappell, J. 2008. The evolution of weathering profiles through time: new insights from uraniumseries isotopes. Earth and Planetary Science Letters 274: 359-371.

Empresa Brasileira de Pesquisa Agropecuária [EMBRAPA]. 1997. Manual of Methods of Soil Analysis. EMBRAPA, Rio de Janeiro, RJ, Brazil. (in Portuguese).

Fabbrin Pires, E.; Guerra-Sommer, M.; Scherer, C.M.S. 2005. Late Triassic climate in Southernmost Parana Basin (Brazil): evidence from dendrochronological data. Journal of South American Earth Sciences 18: 213-221.

Furian, S.; Barbiero, L.; Boulet, R. 1999. Organization of the soil mantle in tropical Southeastern Brazil (Serra do Mar) in relation to landslides processes. Catena 38: 65-83.

Grant, J.A. 2005. Isocon analysis: a brief review of the method and applications. Physics and Chemistry of the Earth 30: 997-1004.

Heimsath, A.M.; Dietrich, W.E.; Nishiizumi, K.; Finkel, R.C. 1997. The soil production function and landscape equilibrium. Nature 388: 358-361.

Heimsath, A.M.; Chappell, J.; Dietrich, W.E.; Nishiizumi, K., Finkel, R.C. 2000. Soil production on a retreating escarpment in Southeastern Australia. Geology 28: 787-790.

Instituto Brasileiro de Geografia e Estatística [IBGE]. 1986. Survey of Natural Resources. RADAMBRASIL Project. Sheets SH.22, SH.21 and SI.22: Geology, Geomorphology, Vegetation, Potential Land Use. v.33. IBGE, Rio de Janeiro, RJ, Brazil. (in Portuguese).

Jasper, A.; Menegat, R.; Guerra-Sommer, M.; Cazzulo-Klepzig, M.; De Souza, P.A. 2006. Depositional cyclicity and paleoecological variability in an outcrop of Rio Bonito formation, Early Permian, Parana Basin, Rio Grande do Sul, Brazil. Journal of South American Earth Sciences 21: 276-293.

Jimenez Rueda, J.R.; Dematte, J.L.I. 1988. Soils developed from Marilia Formation (Bauru Group) from Monte Alto Region, Sao Paulo State, Brazil. Revista Brasileira de Ciência do Solo 12: 161-170. (in Portuguese, with abstract in English).
Loeppert, R.L.; Inskeep, W.P. 1996. Iron. p. 639-664. In: Sparks, D.L., ed. Methods of soil analysis: Part 3: Chemical methods. American Society of Agronomy and Soil Science Society of America, Madison, WI, USA.

Luz, L.R.Q.P.D.; Santos, M.C.D.; Mermut, A.R. 1992. Pedogenesis in a toposequence of the semiarid region, Pernambuco State, Brazil. Revista Brasileira de Ciência do Solo 16: 95-102. (in Portuguese, with abstract in English).

Mehra, O.P.; Jackson, M.L. 1960. Iron oxide removal from soils and clays by dithionite citrate systems buffered with sodium bicarbonate. Clays and Clay Minerals 7: 317-327.

Mori, P.E.; Reeves, S.; Correia, C.T.; Haunakka, M. 1999. Development of a fused glass disc XRF facility and comparison with the pressed pellet technique at Instituto de Geociências, University of São Paulo. Revista Brasileira de Geociências 29: 441-446.

Muggler, C.C.; Buurman, P.; van Doesburg, J.D.J. 2007. Weathering trends and parent material characteristics of polygenetic Oxisols from Minas Gerais, Brazil: I. Mineralogy. Geoderma 138: 39-48.

Northcote, K.H. 1971. A Factual Key for the Recognition of Australian Soils. Rellim Technical, Glenside, Australia.

Phillips, J.D. 2004. Geogenesis, pedogenesis, and multiple causality in the formation of texture-contrast soils. Catena 58: 275-295.

Phillips. J.D.; Lorz, C. 2008. Origins and implications of soil layering. Earth-Science Reviews 89: 144-155.

Pierini, C.; Mizusaki, A.M.P.; Scherer, C.M.S.; Alves, D.B. 2002. Integrated stratigraphic and geochemical study of the Santa Maria and Caturrita formations (Triassic of the Parana Basin), Southern Brazil. Journal of South American Earth Sciences 15: 669-681.

Poppe, L.J.; Eliason, A.H.; Hastings, M.E. 2004. A Visual Basic program to generate sediment grain-size statistics and to extrapolate particle distributions. Computers \& Geosciences 30: 791-795.

Schaefer, C.E.R.; Ker, J.C.; Gilkes, R.J.; Campos, J.C.; Da Costa, L.M.; Saadi, A. 2002. Pedogenesis on the uplands of the Diamantina Plateau, Minas Gerais, Brazil: a chemical and micropedological study. Geoderma 107: 243-269.

Simas, F.N.B.; Schaefer, C.E.G.R.; Fernandes Filho, E.I.; Chagas, A.C.; Brandao, P.C. 2005. Chemistry, mineralogy and micropedology of highland soils on crystalline rocks of Serra da Mantiqueira, Southeastern Brazil. Geoderma 125: 187-201.

Stiles, C.A.; Mora, C.I.; Driese, S.G. 2003. Pedogenic processes and domain boundaries in a Vertisol climosequence: evidence from titanium and zirconium distribution and morphology. Geoderma 116: 279-299.

United States Department of Agriculture [USDA]. 1993. Soil Survey Manual. USDA, Washington, D.C., USA.

United States Department of Agriculture [USDA-NRCS]. 1999. Soil Taxonomy: A Basic System of Soil Classification for Making and Interpreting Soil Surveys. USDA-NRCS, Washington, D.C., USA.

Whittig, L.D.; Allardice, W.R. 1986. X-ray diffraction techniques. p. 331-362. In: Klute, A., ed. Methods of soil analysis. Part 1: Physical and mineralogical methods. American Society of Agronomy and Soil Science Society of America, Madison, WI, USA.

Received March 19, 2008

Accepted February 23, 2010 